\title{
The SCEC Southern California Reference Three-Dimensional Seismic Velocity Model Version 2
}

\author{
by Harold Magistrale, Steven Day, Robert W. Clayton, and Robert Graves
}

\begin{abstract}
We describe Version 2 of the three-dimensional (3D) seismic velocity model of southern California developed by the Southern California Earthquake Center and designed to serve as a reference model for multidisciplinary research activities in the area. The model consists of detailed, rule-based representations of the major southern California basins (Los Angeles basin, Ventura basin, San Gabriel Valley, San Fernando Valley, Chino basin, San Bernardino Valley, and the Salton Trough), embedded in a 3D crust over a variable depth Moho. Outside of the basins, the model crust is based on regional tomographic results. The model Moho is represented by a surface with the depths determined by the receiver function technique. Shallow basin sediment velocities are constrained by geotechnical data. The model is implemented in a computer code that generates any specified 3D mesh of seismic velocity and density values. This parameterization is convenient to store, transfer, and update as new information and verification results become available.
\end{abstract}

\section{Introduction}

The dense population and active tectonics of southern California necessitate extensive seismic hazard evaluations that include precise earthquake location determinations, path and site effect studies, and strong ground motion simulations. These studies require a realistic three-dimensional (3D) seismic velocity model defined on spatial scales appropriate for each application. Here we describe a 3D seismic velocity model for southern California assembled from geological and geophysical data and designed to serve as a reference model for multidisciplinary research activities in the area.

A velocity model, to be widely useful, must integrate data from multiple disciplines, including seismic imaging, geologic mapping, and geotechnical investigations, in order to capture the wide range of spatial scales that are important for both basic research and earthquake hazard applications. Consider, for example, the problem of deterministic 3D modeling of long period $(>1 \mathrm{sec})$ strong ground motion in southern California. Regional seismic tomography provides 3D seismic velocity information with resolution on the order of tens of kilometers (Magistrale et al., 1992; Zhou, 1994; Hauksson, 2000). This resolution is useful for modeling the propagation of long-period seismic waves in crystalline basement rocks outside of the sedimentary basins, where wavelengths are long and velocity variations are relatively small. In the basins, however, much higher spatial resolution is required: basin depths are typically less than $10 \mathrm{~km}$, and seismic velocities vary dramatically. In the low-velocity basin sediments, 1-sec $S$ waves have wavelengths ranging from a few kilometers in the deep basins, down to only a few hundred meters in the shallow basin layers. Also, important amplification and interference effects are likely to be localized near the basin edges, which therefore need to be well resolved. Geologic mapping, geotechnical investigations, and borehole velocity logs can provide the necessary high spatial resolution.

The Southern California Earthquake Center (SCEC) has supported an effort to develop a standard 3D reference model for southern California. The designation "reference model" is meant to emphasize the following characteristics. (1) The model incorporates contributions from multiple types of data. (2) It represents a standard agreed to among a large number of researchers working in southern California, against which anomalies (in, e.g., seismic travel times, waveforms, and amplitudes; gravity; and borehole data) can be identified, quantified, and compared. (3) The model description is reviewed and maintained by SCEC and made widely available, and its periodic revisions are documented and tracked by version number. (4) By integrating a large, diverse body of both seismic and nonseismic data, the reference model provides a starting model for application of perturbative approaches to the 3D inversion of seismic travel time and waveform data. A prototype reference model (Magistrale et al., 1996; we will refer to it as Version 0) has been widely used for simulating ground motions from past earthquakes (e.g., Wald and Graves, 1998) as well as for estimating basin effects from potential future earthquakes (e.g., Olsen et al., 1996). The need for a single standard reference 
model motivated the much more comprehensive model development reported here.

Version 2 of the SCEC reference model consists of detailed, rule-based representations of the major southern California basins (Fig. 1) embedded in a 3D crust over a variable depth Moho. The model includes the populated Los Angeles area basins (Los Angeles basin, Ventura basin, San Gabriel Valley, San Fernando Valley, Chino basin, and San Bernardino Valley), and the Salton Trough. The basins are parameterized as a set of objects (constructed from geological, geophysical, and geotechnical data) and rules implemented in a computer code that generates any specified 3D mesh of seismic velocity and density values. This parameterization is convenient to store, transfer, and update as new information and verification results become available. It allows any distribution of velocities; for example, fast-over-slow velocities are easily modeled. A fine spatial resolution is achieved by the use of geologic information to constrain the locations and ages of structural and stratigraphic boundaries. Outside of the basins, the model crust is based on regional tomographic results. The model Moho is represented by a surface with the depths determined by the receiver function technique.

Several studies in this special volume (Field, 2000; Lee and Anderson, 2000; Olsen, 2000; Steidl, 2000) use Version 1 of the SCEC reference model (Magistrale et al., 1998). Version 1 contains the Los Angeles area basins in a 1D crust over a constant depth Moho. The Version 1 model improved the Version 0 model of Magistrale et al. (1996) by adding the Ventura basin, Chino basin, and San Bernardino Valley, and revising the San Fernando Valley. Version 2 is an ad- vance over Version 1 in that it includes the Salton Trough, a 3D distribution of crustal velocities outside of the basins, a 3D Moho, and detailed shallow basin velocities from geotechnical logs. The ground-motion simulations reported in this volume (Olsen, 2000) focused on the Los Angeles area basins and imposed a $V_{S}$ lower bound of $1 \mathrm{~km} / \mathrm{sec}$ (due to computational limitations), so the conclusions based on those simulations would be little affected by the Version 2 modifications. Basin depth effects on ground motion reported in this volume (Field, 2000; Lee and Anderson, 2000; Steidl, 2000) use the depth to the $2.5 \mathrm{~km} / \mathrm{sec} V_{S}$ isovelocity surface to define basin depth. In the Los Angeles area basins that isovelocity surface is the same in the Version 1 and Version 2 models.

\section{Model Construction}

\section{Reference Surfaces and Rule Definition}

In the model sedimentary basins, $V_{P}$ is determined by the application of empirical rules to interpolate properties from the model objects, and density and $V_{S}$ are derived from $V_{P}$. Outside and below the basins, $V_{P}$ and $V_{S}$ are assigned by interpolation from the regional tomographic results of Hauksson (2000). Within the basins, $V_{P}$ and $V_{S}$ in the top $300 \mathrm{~m}$ are constrained by geotechnical borehole seismic velocity data. Where $V_{P}$ and $V_{S}$ are independently specified, the density is derived from $V_{P}$.

There exists a great deal of information about the age and depth of the sediments in the Los Angeles area basins from oil and water exploration activities and other geologic

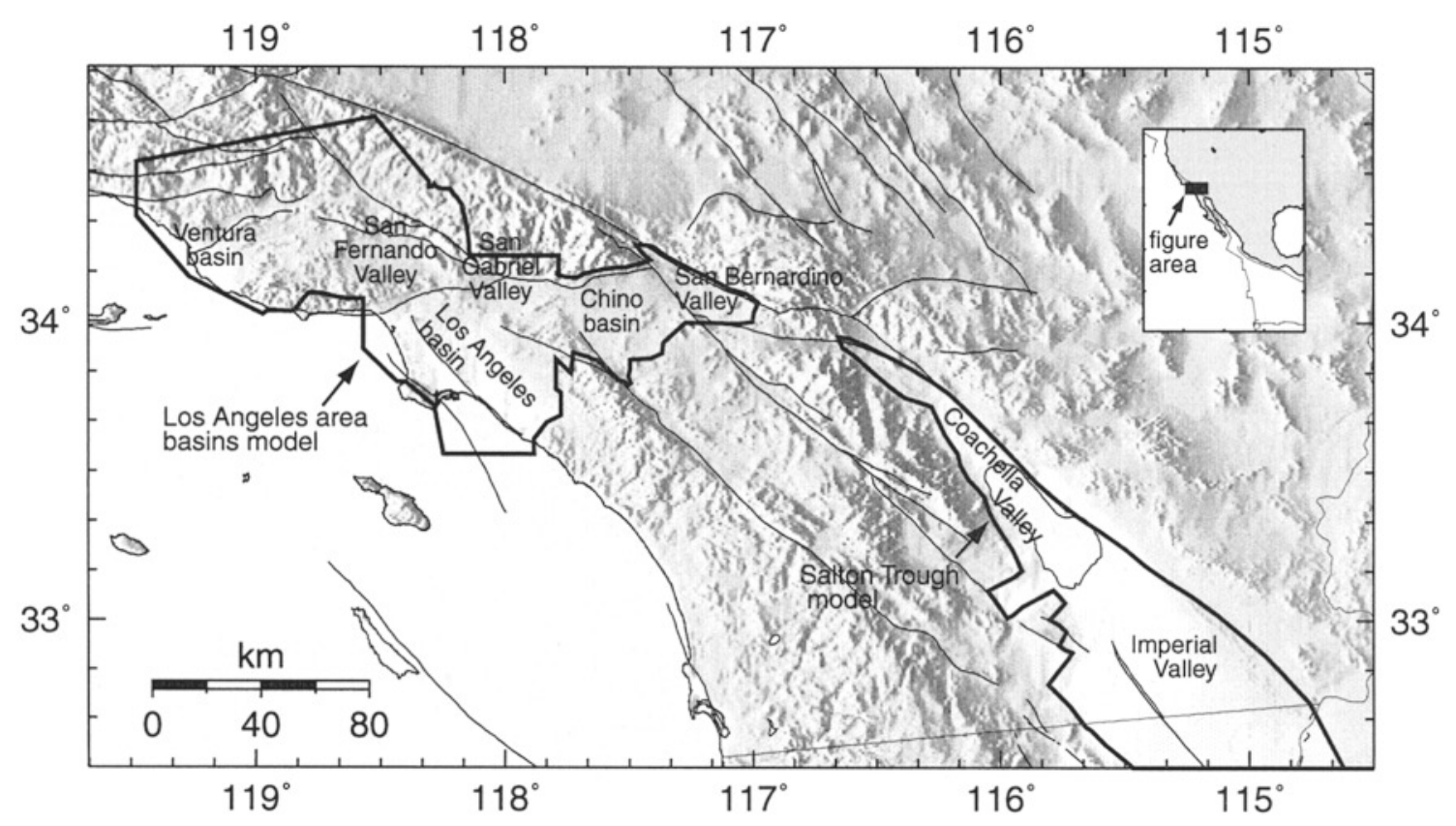

Figure 1. Location map of southern California showing the extent of the basin models (heavy black lines) and basin names. Light black lines are faults. Inset shows location of figure area; western North America is shaded. 
studies (Fig. 2). From this information, we define reference surfaces (objects) of known depth and age in the detailed portion of the model representing the sedimentary basins. We examine structural cross sections and maps to define widespread, well-defined reference surfaces representing stratigraphic horizons, sediment-basement contacts, and faults (many of the surfaces are in multiple pieces). The maps and cross sections are digitized, and the reference surfaces are carefully interpolated and resampled on regular grids with a spacing of 100 to 300 meters. Uplift of each reference surface is estimated, or sometimes has been explicitly mapped (e.g., Wright, 1991).

Faust (1951) examined well surveys from North America and determined an empirical relation between sediment age, depth, and $P$-wave seismic velocity:

$$
V_{P}=k(d a)^{1 / 6}
$$

where $V_{P}$ is $P$-wave velocity, $d$ is the maximum depth of burial of the sediments, $a$ is the sediment age, and $k$ is a constant. The one-sixth power reflects the tendency of sediments to compact as they are buried and to indurate as they age (Dobrin, 1976). Age at any point in a basin can be interpolated from the reference surfaces. The constant $k$ is calibrated for each reference surface by comparison to oil well sonic logs and seismic refraction surveys. At each point of interest within a basin (defined by a latitude, longitude, and depth) for which the velocity is desired: (1) The age and $k$ of the point are interpolated by comparing the point depth to the depths, ages, and $k$ values of the reference surfaces at the same latitude and longitude. (2) The maximum depth of burial is found by correcting the current depth by any known amount of uplift. (3) $V_{P}$ is determined from the Faust equation. (4) Other physical parameters are derived: density is found from $V_{P}$ using the relation of Nafe and Drake (1960); density is used to find Poisson's ratio with the relation of Ludwig et al. (1970); $V_{S}$ is calculated from the $P$-wave velocity and Poisson's ratio.

The seismic velocity structure of the Salton Trough has been characterized by several seismic refraction studies (Fuis et al., 1982, 1984; Mooney and McMechan, 1982; Parsons and McCarthy, 1996). Thus, instead of constructing reference surfaces from sediment stratigraphy information, the Salton Trough is modeled by digitizing $V_{P}$ cross sections derived from the seismic refraction lines (Fig. 2) and converting the cross sections into isovelocity surfaces. At a point of interest, $V_{P}$ is interpolated from the isovelocity surfaces, and the other properties are derived from $V_{P}$ as in step 4 mentioned previously.

\section{Los Angeles Basin and San Gabriel Valley}

Wright (1991), in an extensive summary, presents structure-contour maps of two widespread sedimentary stratigraphic horizons: the base of the Repetto Formation, about 4.5 Ma; and the base of the Mohnian Stage, about 14 Ma. Age control of the stratigraphic horizons is from microfossils
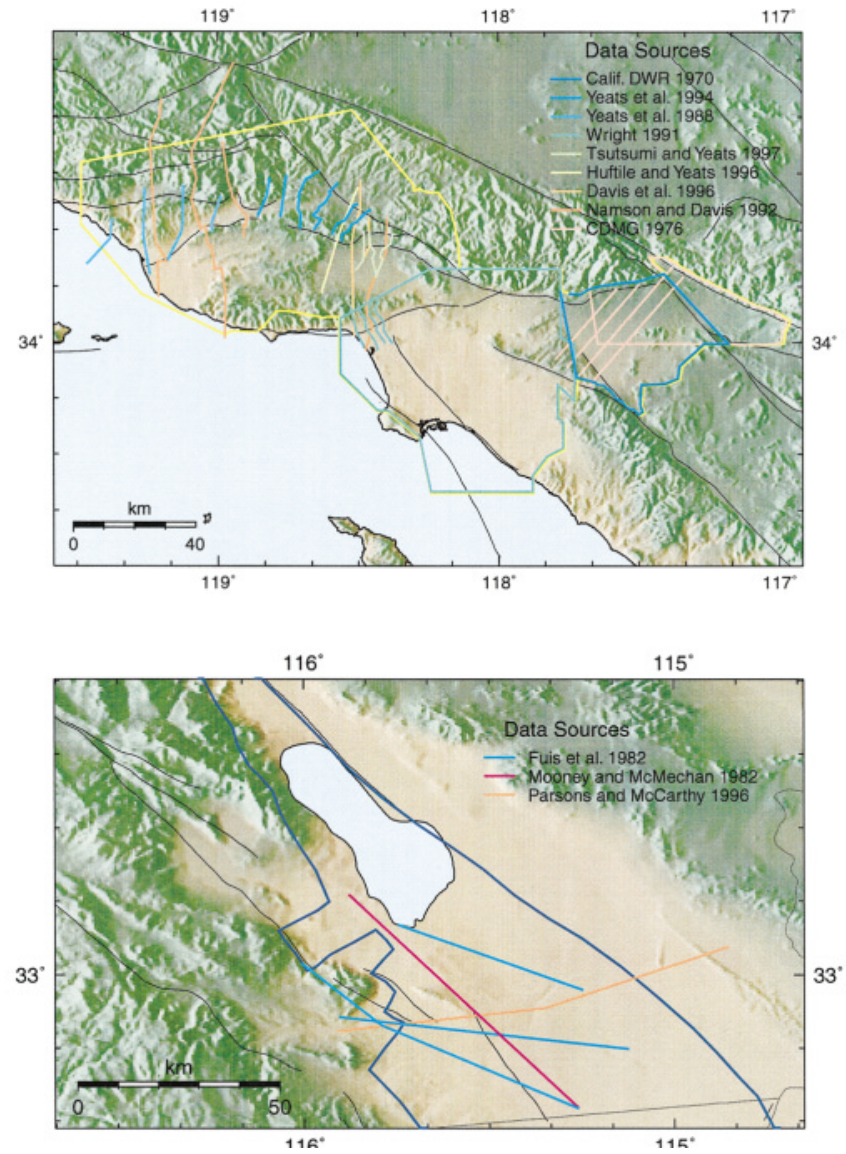

Figure 2. Sources of the information used to construct the basin model reference surfaces for the Los Angeles area (top panel) and Salton Trough (lower panel).

(e.g., Blake, 1991). Wright (1991) also presents a contour map of the amount of uplift during the Pasadenan deformation (3.5 Ma to present); we use this information to correct current sediment depths to depth of maximum burial. McCulloh (1960) and Yerkes et al. (1965) show a structurecontour map of the top of crystalline basement rocks inferred mainly from gravity data. The age we use for this horizon is not the rock age, but rather an early Miocene age (20 Ma) that just predates the development of major basement relief and so dates the base of the sediment fill. The age and distribution of material at the ground surface is indicated on California Division of Mines and Geology (CDMG) geologic maps (Jennings, 1962; Rogers, 1965, 1967; Jennings and Strand, 1969).

The Santa Monica area within the Los Angeles basin is of particular interest to strong-motion modelers because of the unexpectedly high damage to the area from the Northridge earthquake (e.g., Gao et al., 1997). Wright (1991) shows four detailed cross sections that we use to refine the Mohnian, Repetto, and basement surfaces in that area.

We calibrate the model by adjusting the constant $k$ in the Faust relation (equation 1) to match seven oil well sonic 
logs (Fig. 3) in the Los Angeles basin and the San Gabriel Valley (Brocher et al., 1998). In the Los Angeles basin, $k$ $=197$; in the San Gabriel Valley, $k=218$. The sonic logs indicate a $V_{P}$ inversion within the sediments of the San Gabriel Valley. The inversion starts at a constant fraction (0.6) of the depth to the Mohnian reference surface and reaches a constant $\sim 1250 \mathrm{~m} / \mathrm{sec}$ about $400 \mathrm{~m}$ deeper. The inversion is modeled by subtracting the $1250 \mathrm{~m} / \mathrm{sec}$ from the calculated velocities, tapering the subtraction over the top $400 \mathrm{~m}$ of the inversion.

This version of the Los Angeles basin and the San Gabriel Valley differs from Version 0 in the different values of $k$ calibrated from the oil well sonic logs, the San Gabriel Valley velocity inversion, and the Santa Monica area details. The current Los Angeles basin and San Gabriel Valley in Version 2 are the same as in Version 1, except for the geotechnical constraints described subsequently.

San Fernando Valley and Ventura Basin

The San Fernando Valley and the Ventura basin share similar stratigraphy and so are considered together. Yeats $e t$ al. (1988, 1994), Namson and Davis (1992), Huftile and Yeats (1996), Davis et al. (1996), and Tsutsumi and Yeats (1999) present structural cross sections of the San Fernando Valley and the Ventura basin from which we define a total of 12 reference surfaces in 57 pieces. The lateral extent of the reference surfaces at the Earth's surface is from a CDMG geologic map (Jennings and Strand, 1969).

The 11 reference surfaces in the Ventura basin have ages of $0.5,0.975,1.5,2.3,5.0,24,37,47,67,75$, and 100 Ma; lacking independent calibration, we set $k=180$ for all those surfaces to produce model velocities in the deepest sediments approaching the velocities of the surrounding basement rock. In the San Fernando Valley, the seven references surfaces have ages of 2.0,2.3, 5.0,37, 67, 75, and 100 Ma. Four oil well sonic logs (Fig. 3) are available in the San Fernando Valley (Brocher et al., 1998); from these we determine a different $k$ for each reference surface $(k=189$, $189,160,180,123,180,180$, respectively). We correct current sediment depth to maximum depth of burial by calculating the average depth of each reference surface and, because the strata are deformed largely by relatively recent $(<1$ Ma, e.g., Huftile and Yeats, 1995) activity, assume any depth above the average depth was formerly at least as deep as the average. If the current depth is below the average depth, the current depth is used as the maximum depth of burial.

This version of the San Fernando Valley supplants the Version 0 model. It uses entirely new reference surfaces, and new $k$ values calibrated to oil well sonic logs in the valley. The Version 0 model did not include the Ventura basin. The Version 2 San Fernando Valley and Ventura basin are the same as in Version 1, except for the geotechnical constraints described subsequently.

San Bernardino and Chino Basins

The Chino and San Bernardino basins are shallow (generally $<1 \mathrm{~km}$ deep) basins filled mostly with terrestrial sed-

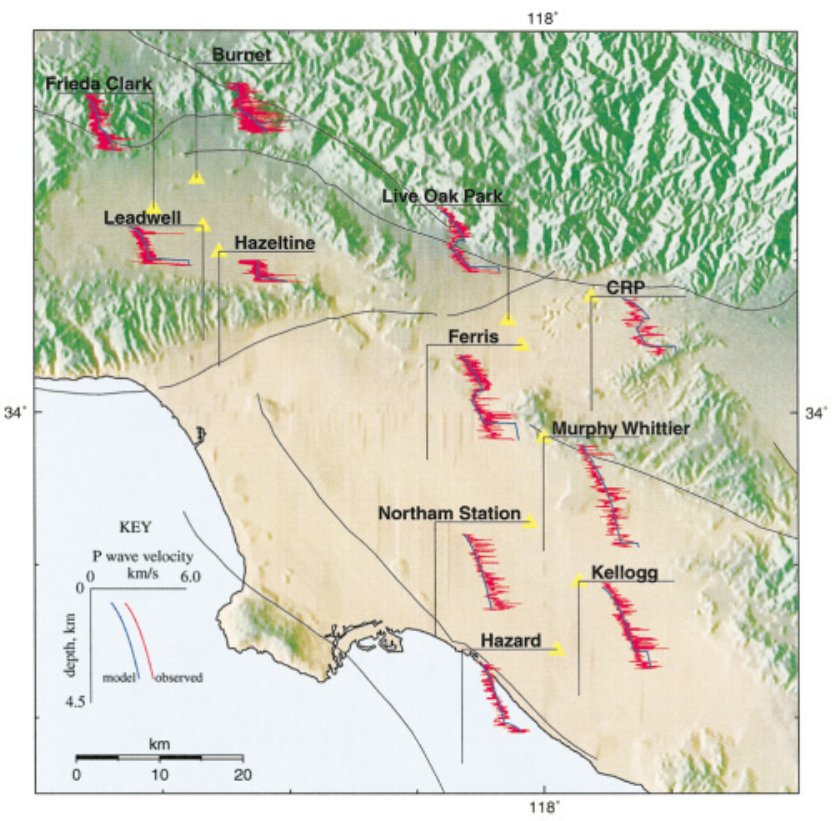

Figure 3. Oil well sonic logs (red) from Brocher et al. (1998) in the Los Angeles basin, San Gabriel Valley, and San Fernando Valley used to calibrate the model (blue). Yellow triangles indicate oil well locations.

iments. We use structural cross sections and maps of the depth to the base of water-bearing strata from Department of Water Resources (1970) and Fife et al. (1976) to define three reference surfaces: a $14.5 \mathrm{Ma}$ Mohnian and a $6.0 \mathrm{Ma}$ Miocene (both limited to the westernmost portion of the Chino basin), and the base of the water bearing strata. The age and distribution of material at the ground surface is from CDMG geologic maps (Rogers, 1965; 1967).

Hadley and Combs (1974) obtained a seismic refraction profile in San Bernardino basin. We note that the top of their $2.9 \mathrm{~km} / \mathrm{sec} V_{P}$ layer corresponds to the base of the water bearing strata, and we interpret the top of that $2.9 \mathrm{~km} / \mathrm{sec}$ layer to correspond to the top of weathered crystalline basement rock. Below the $2.9 \mathrm{~km} / \mathrm{sec}$ layer, Hadley and Combs (1974) defined a $5.3 \mathrm{~km} / \mathrm{sec}$ layer that we interpret to represent hard rock, and we define a hard rock reference surface at a constant depth below the weathered basement surface to mark the bottom of the basin. We compare model velocity profiles to the seismic refraction profile and calibrate the model by adjusting the nominal ages of the weathered and hard basement surfaces (while keeping $k$ fixed at 180) to match the refraction results. The final ages are 6.0 and 16.5 Ma, respectively.

Frankel (1993) combined the Hadley and Combs (1974) refraction profile and water well logs to develop a model of the San Bernardino basin to use in ground-motion simulations. That model used the base of water bearing strata in the well $\operatorname{logs}$ and the top of the $5.3 \mathrm{~km} / \mathrm{sec}$ refraction profile layer to define the top of the basement, and thus is dominated 
by a deep basement trough at the refraction profile site. The current basin model differs greatly by having a relatively flat bottom because of our identification of the top of the $2.9 \mathrm{~km} /$ sec layer as the base of the water-bearing strata. The Version 0 model did not include the San Bernardino and Chino basins; these basins in Version 2 are the same as in Version 1, except for the geotechnical constraints described subsequently.

\section{Geotechnical Constraints}

It is desirable to have well-constrained, detailed shallow properties $(<300 \mathrm{~m}$ depth) in the model because (1) shear waves in low-velocity, shallow sediments at frequencies relevant to engineered structures have wavelengths of a few hundred $\mathrm{m}$ or less, and so the model requires definition at that scale; (2) since shallow $S$-wave impedance has an especially strong role in determining ground-motion amplification (Boore et al., 1993; Anderson et al., 1996; Day, 1996) and because $V_{P} / V_{S}$ can be highly variable in unconsolidated, possibly saturated shallow material, it is important to have direct $V_{S}$ estimates in the near surface rather than relying on the empirical $V_{P} / V_{S}$ relation used elsewhere in the model; and (3) some long-period modeling efforts (Graves, 1995) suggest that near-surface, small-scale structures significantly influence the amplitude and duration of recorded waveforms.

W. Silva (personal comm., 1999) compiled $V_{P}$ and $V_{S}$ measured for geotechnical studies in several hundred boreholes by various organizations. The boreholes are tens to hundreds of meters deep, and borehole coverage (Fig. 4) is dense in the Los Angeles area basins. These data provide direct constraints for the shallow parts of the model basins.

To incorporate the geotechnical data into the velocity model we must interpolate point measurements (borehole velocities at a given depth) over the model area while also preserving the geologic boundaries separating different surface geology types. The latter is important because different surface geologies can have different ground-motion responses (e.g., Silva et al., 1999). We use the detailed NEHRP category (Martin, 1994) classification map developed by the California Division of Mines and Geology (CDMG) (Wills et al., 2000) (Fig. 4). The map plots, with uniform statewide coverage, surface regions classified by NEHRP site category based on the average shear-wave velocity in the top $30 \mathrm{~m}$; the site category regions are outlined by geologic boundaries. The CDMG added the intermediate site categories $\mathrm{BC}, \mathrm{CD}$, and DE to the original NEHRP site categories $\mathrm{B}, \mathrm{C}$, and $\mathrm{D}$ that are present in southern California. We calculate average $V_{P}$ and $V_{S}$ velocity-depth profiles for each site category by finding, for a given depth, the log normal mean value of the velocities of every borehole in the site category. The mean profiles are determined to maximum depths $(25$ to $150 \mathrm{~m}$ ) controlled by the number of samples at each depth; at least three samples are required. Interestingly, the mean $V_{S}$ profiles of two site types (CD and D) vary by basin for depths below $30 \mathrm{~m}$ (Fig. 5), with $V_{S}$ lower in the Los Angeles basin than in the San Gabriel and San Fernando Valleys. The difference may be because the Los Angeles basin is further from the sediment sources north and

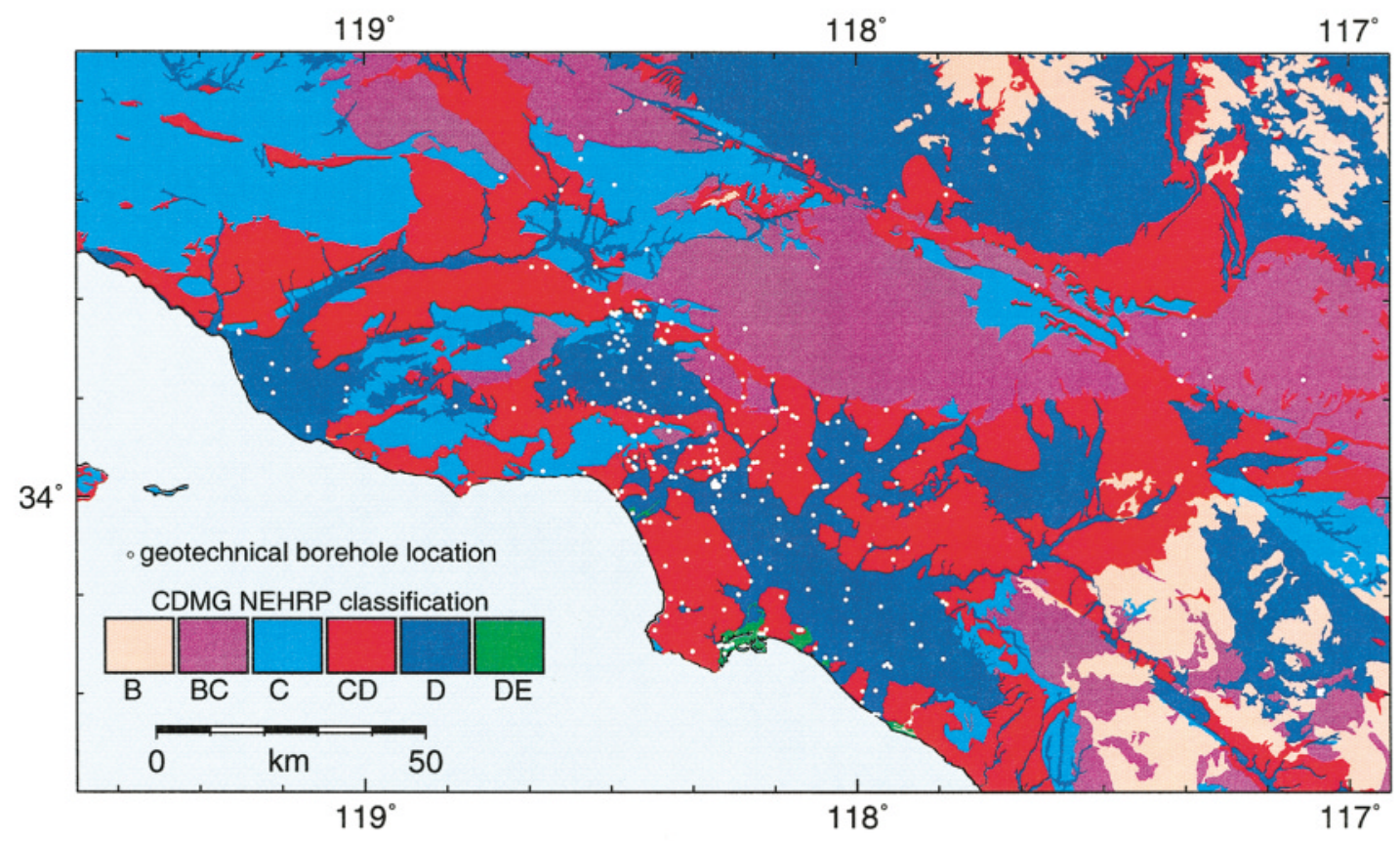

Figure 4. Geotechnical borehole locations (white circles; W. Silva, personal comm.) and the CDMG NEHRP site classifications (Wills et al., 2000) for the Los Angeles region. 


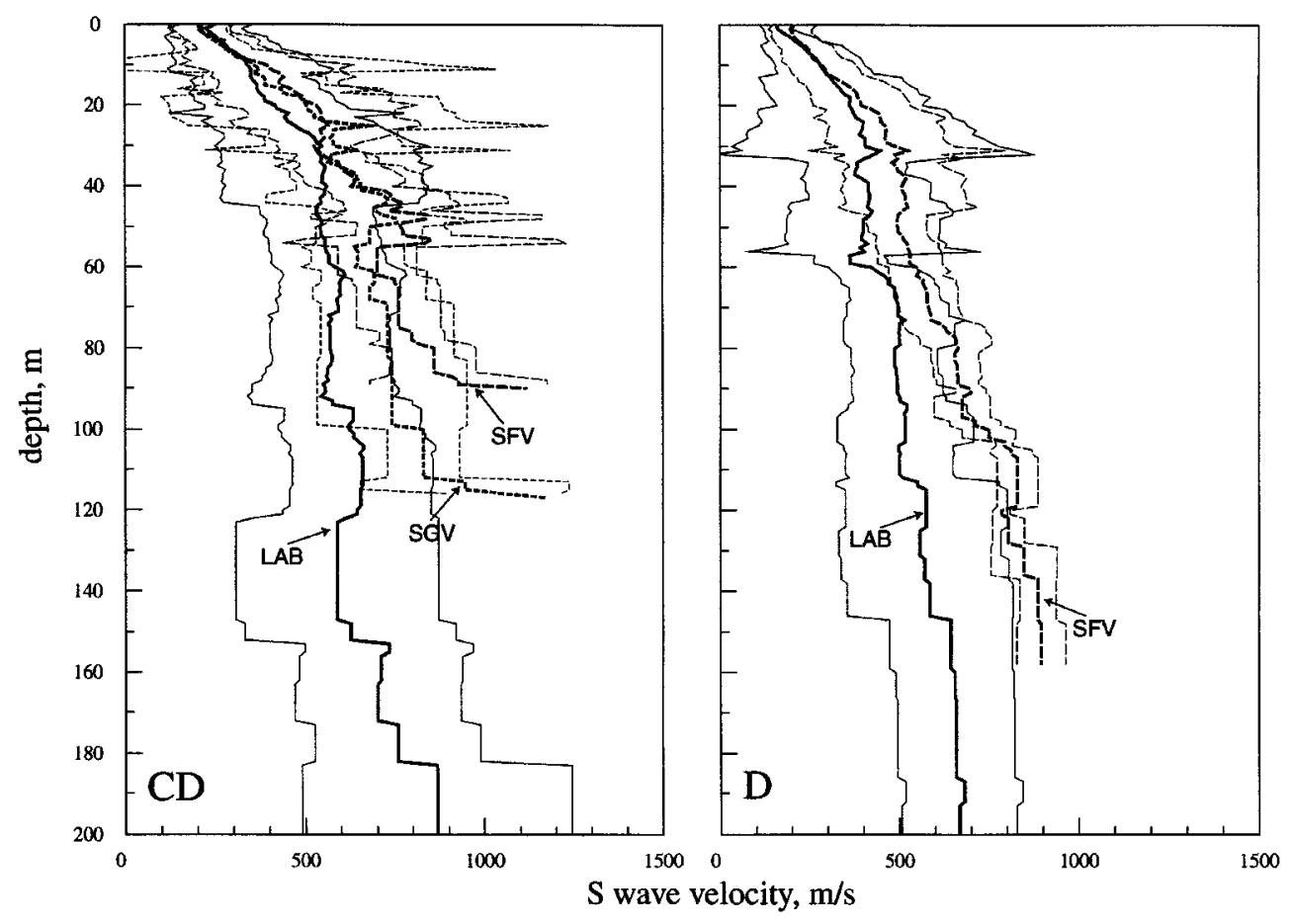

Figure 5. Mean (unsmoothed log-normal) $V_{\mathrm{S}}$ profiles (thick lines) of site categories $\mathrm{CD}$ and D for the Los Angeles basin (LAB, solid), San Fernando Valley (SFV, long dashes), and San Gabriel Valley (SGV, short dashes). Note differences below $30 \mathrm{~m}$ depth. Thin lines are $\pm 1 \sigma$; the number of samples varies from 3 to 88 at different depths.

east of the basins than the two valleys, and so receives finer grained, seismically slower sediments. We use basin-specific mean profiles (defined by finding the mean velocities of the boreholes of each site type within each basin) for site types $\mathrm{CD}$ and D.

Separate $V_{P}$ and $V_{S}$ mean profiles for all the site categories are used; the $V_{S}$ profiles are smoothed by eye to remove minor velocity inversions that result from the averaging process. $V_{P} / V_{S}$ values derived from the (unsmoothed) mean profiles are about 1.7 to 2.5 in site category $\mathrm{C}$, about 1.7 to 3.5 in site categories CD and D (except for in the San Gabriel Valley, where category $\mathrm{D} V_{P} / V_{S}$ reaches about 5.5), and up to about 9.5 in category DE (Fig. 6). Site category BC had too few $V_{P}$ data to calculate $V_{P} / V_{S}$.

The velocity at a specific shallow point is found by (1) looking up the site category the point is in; (2) looking up nearby ( $<5 \mathrm{~km}$ distance) boreholes in the same site category with data at the same depth as the point; and (3) assigning the velocity as a weighted combination of the appropriate mean profile and nearby boreholes. If there are no nearby boreholes the velocity from that site type mean profile is used. This allows reasonable velocity values to be assigned to the areas where geotechnical data are sparse. If the point is within $50 \mathrm{~m}$ of a borehole, the velocity from that borehole is used, so the original borehole data can be recovered. Between $50 \mathrm{~m}$ and $2 \mathrm{~km}(2 \mathrm{~km}$ and $5 \mathrm{~km})$ the boreholes and generic profile are weighted by $2 / 3$ and $1 / 3(1 / 3$ and $2 / 3)$,

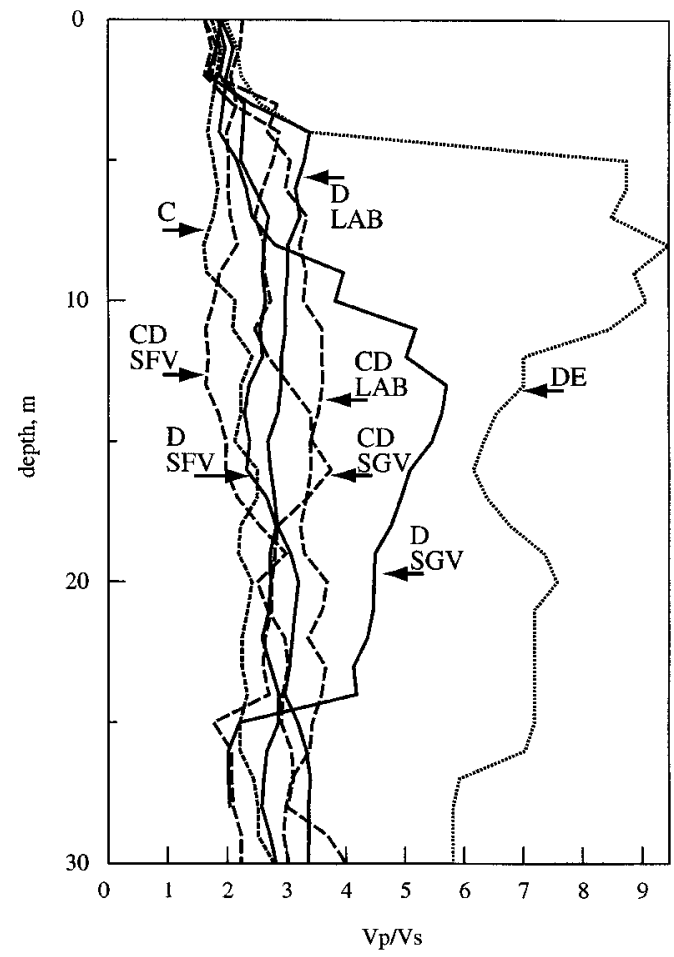

Figure 6. $V_{P} / V_{S}$ for site categories $\mathrm{C}$ (short dashes), CD (long dashes), D (solid), and DE (dots). Abbreviations as in Figure 5. 
respectively. The weighting scheme preserves impedance contrasts between site category regions while allowing smooth variations within a site category region. Below the maximum depth of the mean profiles, $V_{S}$ is extrapolated using velocity-depth gradients from the deepest boreholes (Silva et al., 1999; W. Silva, personal comm., 2000) and compared to $V_{S}$ calculated by the rule-based scheme. The extrapolated $V_{S}$ is used until it reaches a value equal to the rule-based value, typically between 100 and $300 \mathrm{~m}$ depth; below $300 \mathrm{~m}$, the rule-based $V_{S}$ is always used. $V_{P}$ is determined by a weighted sum of the bottom of the generic profiles and the rule-based velocities, so that the two smoothly merge at $200 \mathrm{~m}$ depth. That depth was determined by comparing the borehole profiles with trial model predictions. The geotechnical constraints are implemented in the Los Angeles area basins (Los Angeles basin, Ventura basin, San Gabriel Valley, San Fernando Valley, Chino basin, and San Bernardino Valley) but not elsewhere in the model. These constraints are not present in any previous versions of the reference model.

\section{Salton Trough}

The Salton Trough has been subject to seismic refraction studies by Fuis et al. (1982), Fuis and Kohler (1984), Mooney and McMechan (1982), and Parsons and McCarthy (1996). They present $V_{P}$ cross sections (Fig. 2) derived from the refraction results. Following Magistrale (1999), we digitize the cross sections and define five isovelocity reference surfaces of $2.5,5.5,6.0,6.5$, and $7.0 \mathrm{~km} / \mathrm{sec}$. We fix the surface $V_{P}$ at $1.8 \mathrm{~km} / \mathrm{sec}$, consistent with all the refraction studies. Parsons and McCarthy (1996) determine a $22 \mathrm{~km}$ deep Moho, with an upper mantle $V_{P}$ of about $7.7 \mathrm{~km} / \mathrm{sec}$; we use those values. Lower crustal $V_{P}$ determinations vary from $6.9 \mathrm{~km} / \mathrm{sec}$ (Parsons and McCarthy, 1996) to about 7.5 $\mathrm{km} / \mathrm{sec}$ (Fuis et al., 1982). We fix the $V_{P}$ just above the Moho to $7.1 \mathrm{~km} / \mathrm{sec}$, producing a gentle gradient between the 7.0 $\mathrm{km} / \mathrm{sec}$ surface and the $22 \mathrm{~km}$ deep Moho, and a sharp jump to the upper mantle $7.7 \mathrm{~km} / \mathrm{sec} V_{P}$.

The seismic lines constraining the model are in the Imperial Valley (the southern part of the Salton Trough). Areas outside of the Imperial Valley, but still within the Trough (e.g., the Coachella Valley) are assigned $V_{P}$ from a velocitydepth profile determined within the Imperial Valley. The lack of control on the Coachella Valley sediment velocities and basement configuration mean that this part of the model is relatively crude. The Salton Trough is not present in any previous versions of the model.

\section{Crustal Model}

The seismic velocity model requires realistic velocities to represent the rocks outside of the rule-based basin models. Tomographic results (Hauksson, 2000) from the inversion of local earthquake travel times recorded on the southern California seismic network provide 3D basement rock $V_{P}$ and $V_{S}$ values. Those velocities are determined on a $15 \mathrm{~km}$ $\times 15 \mathrm{~km}$ grid covering southern California at 9 depths (1.0,
$4.0,6.0,10.0,15.0,17.0,22.0,31.0$, and $33.0 \mathrm{~km}) . V_{P}$ and $V_{S}$ at a point outside of the basins is determined by interpolation of the velocities of the eight tomography grid nodes surrounding the point.

The tomographic calculations used an initial 1D model based on Hadley and Kanamori (1977) that did not include the model Los Angeles area basins. The compatibility of travel times upon the insertion of the basins into the tomographic background is tested by replacing the final tomography values at grid nodes within the basins with velocities from the basin models, and performing an additional iteration of the travel-time inversion. Around the basin edges, the results show the influence of the basin low velocities smeared over 4 to 5 grid lengths into the surrounding crust as concentric bands of slightly $(<4 \%)$ higher and lower velocities relative to the velocities found in the original tomography results. Away from the basins, the velocity differences are $<1 \%$. Because the smearing is an artifact of the tomography method, and the changes elsewhere are small, we conclude that the basins model is compatible with regional travel-time data.

The incorporation of tomographically determined velocities outside the basins is new to Version 2. The Version 0 and 1 models use a 1D, depth-dependent crustal model from Hadley and Kanamori (1977).

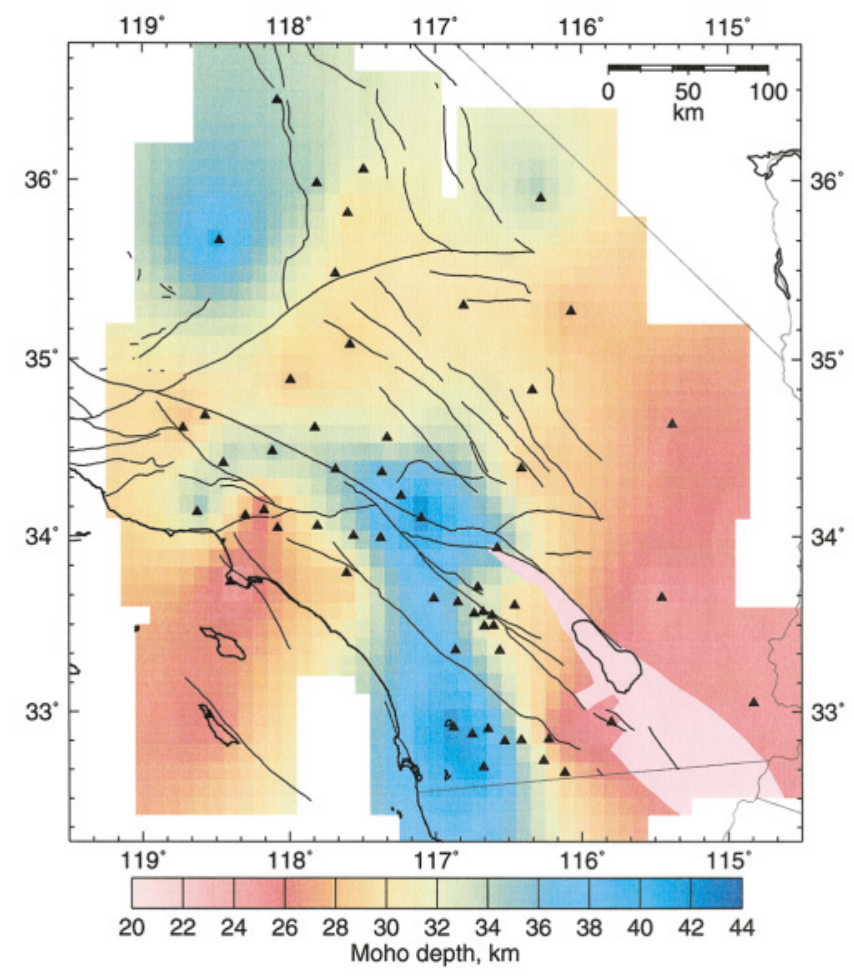

Figure 7. Model Moho surface. Moho depths are found using the receiver-function technique and regional tomography crustal velocities except in the Salton Trough where the Moho depth is fixed at 22 $\mathrm{km}$. Triangles indicate broadband station locations. 


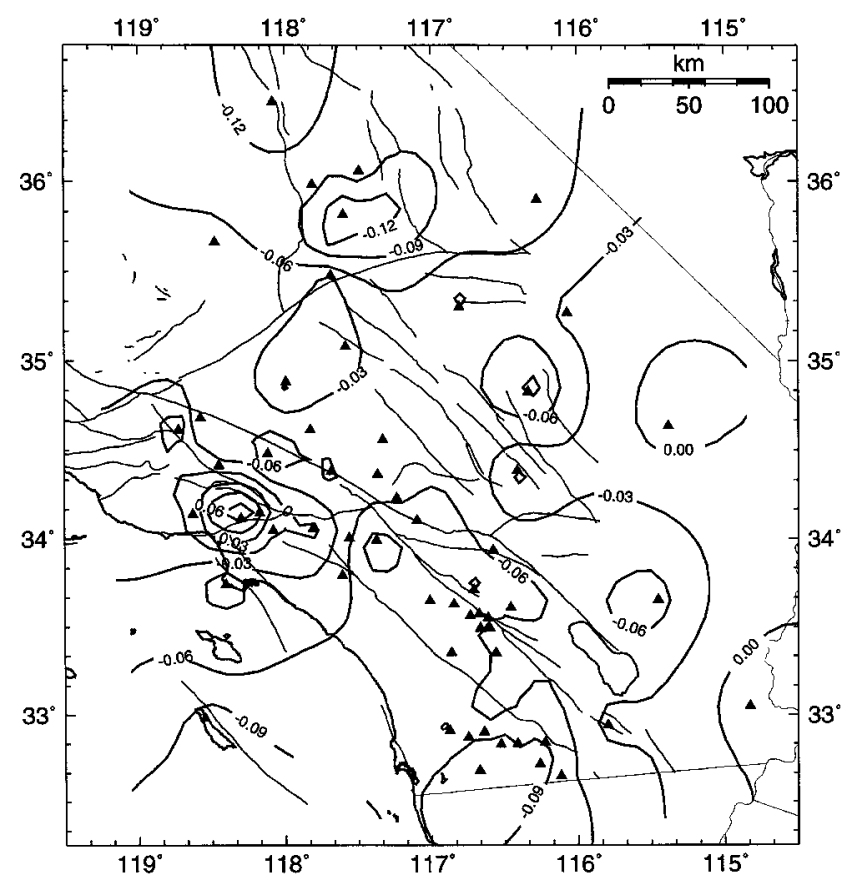

Figure 8. Contours of $V_{P} / V_{S}$ differences between the tomographic crustal velocities of Hauksson (2000) and multiple converted phase-stacking technique of Zhu and Kanamori (2000). Note that the tomographic $V_{P} / V_{S}$ are generally lower (negative differences) than the stacking technique values. Triangles indicate broadband station locations. Contour interval is 0.03 .

Moho

A well characterized, variable depth Moho is a desirable element of the model not only to accurately model the regional distribution of seismic velocities, but also to constrain models of the tectonic evolution of the region. We determine the crustal thickness of southern California using $P s$ minus $P$ times measured from receiver functions of teleseismic events recorded at broadband stations, and crustal velocities determined by tomographic analysis of local earthquake travel times.

We use the receiver functions determined at $\sim 70$ sites by Zhu and Kanamori (2000) and the 3D crustal $V_{P}$ and $V_{S}$ regional tomography models of Hauksson (2000). For each recording site, we construct $V_{S}$ and $V_{P}$ crustal velocity profiles from the 3D tomography results. These crustal velocities, described previously, are used to produce a self-consistent model. Moho depths are obtained from the $P s$ minus $P$ times by adjusting the thickness of the lower crust to match the differential travel times.

The receiver function point determinations of Moho depth are converted (via minimum curvature gridding) into a surface and resampled onto a $6^{\prime}$ by $6^{\prime}$ grid (Fig. 7). Under the Salton Trough, the Moho depth is fixed at $22 \mathrm{~km}$ depth. A point of interest is tested to determine if it is above or below the Moho: if below, a $V_{P}$ of $7.8 \mathrm{~km} / \mathrm{sec}$ is assigned

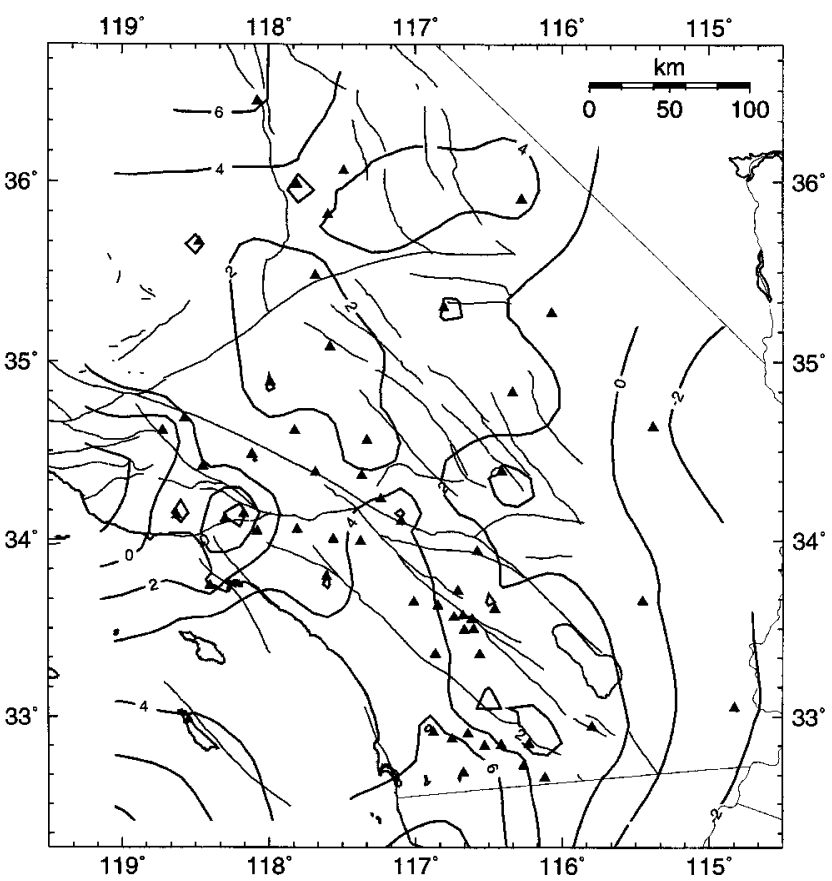

Figure 9. Contours of the differences between the receiver function Moho depths of the current work and those of Zhu and Kanamori (2000). Note that the current work depths are generally deeper (positive differences). Triangles indicate broadband station locations. Contour interval is $2 \mathrm{~km}$.

(based on Hadley and Kanamori, 1977), except in the Salton Trough, where an upper mantle $V_{P}$ of $7.7 \mathrm{~km} / \mathrm{sec}$ is used (Parsons and McCarthy, 1996). Future model versions will incorporate 3D upper mantle velocities.

Crustal thickness found from receiver functions is a strong function of $V_{P} / V_{S}$. We estimate the uncertainties in the Moho depth determination by comparing different $V_{P} /$ $V_{S}$ models and the Moho depths calculated from those models. Zhu and Kanamori (2000) calculate crustal thickness and a vertically integrated $V_{P} / V_{S}$ with a receiver function stacking technique that exploits the converted phase multiples to constrain the tradeoff between crustal thickness and $V_{P} / V_{S}$. Hauksson (2000) and Zhou (1994) performed tomographic inversions of local earthquake travel times to determine $V_{P}$ and $V_{S}$ structure. The vertically integrated crustal $V_{P} / V_{S}$ of the two tomographic studies are similar, and both tend to be lower than the $V_{P} / V_{S}$ found by stacking (Fig. 8). The Moho depths found here using the tomographic $V_{P}$ and $V_{P} / V_{S}$ are typically 2 to $4 \mathrm{~km}$ deeper than the Moho depths found by Zhu and Kanamori (2000) (Fig. 9); by comparison, the Moho depth errors they estimate at all sites average to $\pm 0.9 \mathrm{~km}$.

\section{Model Application and Availability}

The southern California reference seismic velocity model (Figs. 10 and 11) is suitable for a variety of applications. As a reasonable description of crustal properties, the 


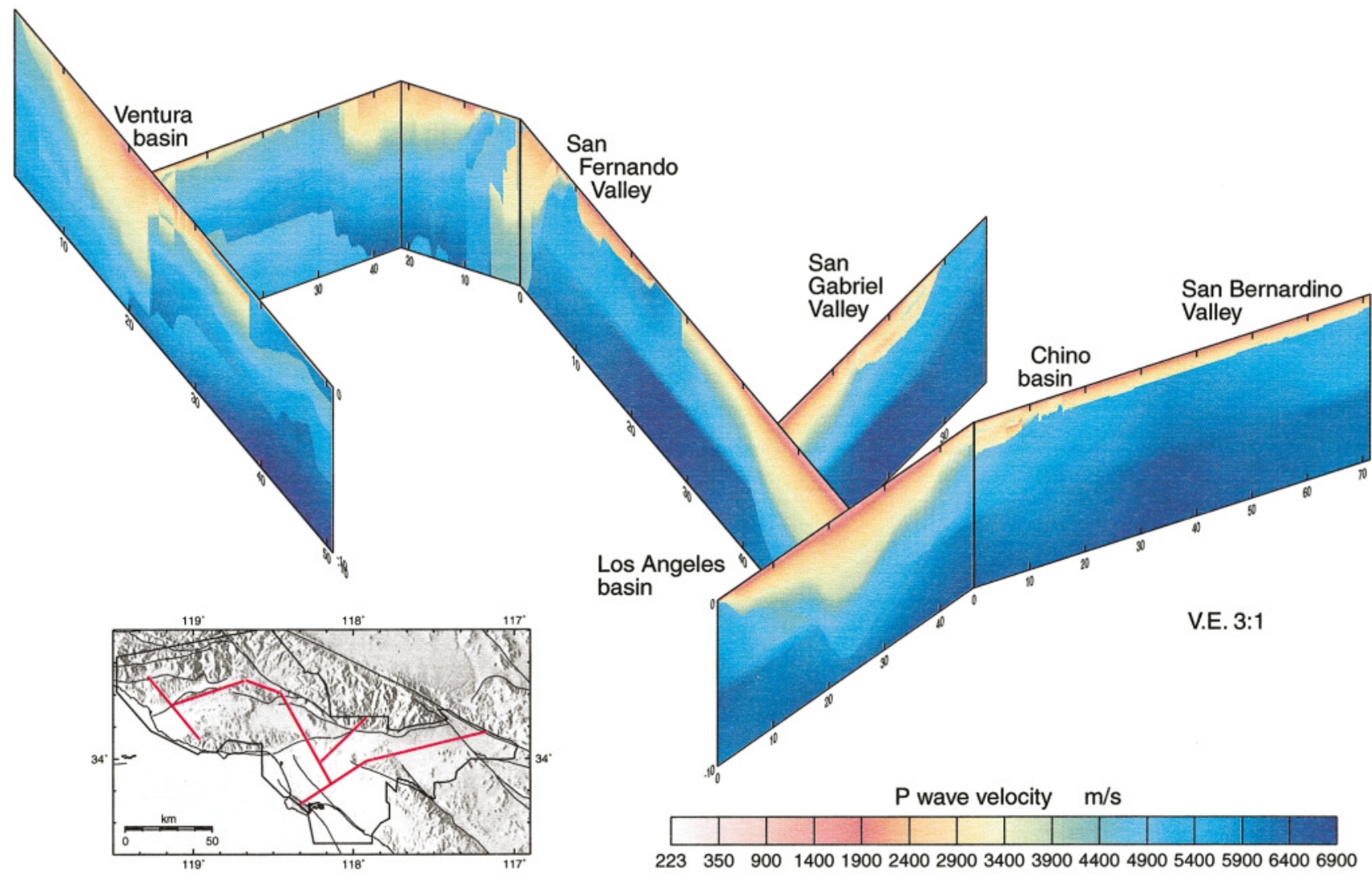

Figure 10. Fence diagram of $P$-wave velocity in and around the Los Angeles region basins. Cross section locations shown as red lines in lower left panel. Seismic velocities in the basins are controlled by rule-based models within the basins, and by tomographic results outside the basins. See Field et al. (2000) for an $S$-wave velocity fence diagram.

Version 0 and 1 models have been used to model basin effects on ground motions from past (e.g., Day et al., 1994) and potential future earthquakes (e.g., Olsen et al., 1996), to incorporate basin structure into earthquake ground-motion attenuation relations (Lee and Anderson, 2000; Steidl, 2000; Field, 2000), and to perform 3D source inversion for southern California earthquakes (Liu and Archuleta, 1999).

The reference model may be appropriate for use as a starting model in perturbation studies, such as linearized inversions of travel times for crustal velocities (e.g., Magistrale, 1999) or of seismic waveforms for crustal structure. SCEC has supported investigations to verify and improve the model, for example, testing the ability of the model to produce synthetic waveforms that match observations of recent, well-recorded earthquakes, such as Landers and Northridge (Graves et al., 1999; Olsen, 2000), and testing how well the model densities can fit gravity observations (Roy and Clayton, 1999).

Version 2 of the standard three-dimensional seismic velocity model for southern California is available as a FORTRAN source code and associated files on the SCEC Data Center website at http://www.scecdc.scec.org.

\section{Acknowledgments}

Discussions with W. Silva were helpful in constructing the model. We thank L. Zhu, E. Hauksson, and W. Silva for providing data and research products used in the model, and John Tinsley and Tom Brocher for thoughtful reviews of the manuscript. Many figures were made using the GMT plotting package (Wessel and Smith, 1991). This research was supported by the Southern California Earthquake Center (SCEC). SCEC is funded by NSF Cooperative Agreement EAR-8920136 and USGS Cooperative Agreements 14-08-0001-A0899 and 1434-HQ-97AG01718. The SCEC contribution number for this paper is 509. Partial support came from NSF KDI program Award CMS-9980063. The Salton Trough model development was supported by NSF Award EAR-9725536.

\section{References}

Anderson, J. G., Y. Lee, Y. Zeng, and S. M. Day (1996). Control of strong motion by upper 30 meters, Bull. Seism. Soc. Am. 86, 1749-1759.

Blake, G. H. (1991). Review of the Neogene biostratigraphy and stratigraphy of the Los Angeles basin and implications for basin evolution, AAPG Memoir 52, 135-184.

Boore, D. M., W. B. Joynor, and T. E. Fumal (1993). Estimation of response spectra and peak accelerations from western North America earthquakes: an interim report, U. S. Geol. Surv. Open-File Rept. 93-509, $72 \mathrm{pp}$.

Brocher, T., A. Ruebel, T. Wright, and D. Okaya (1998). Compilation of 

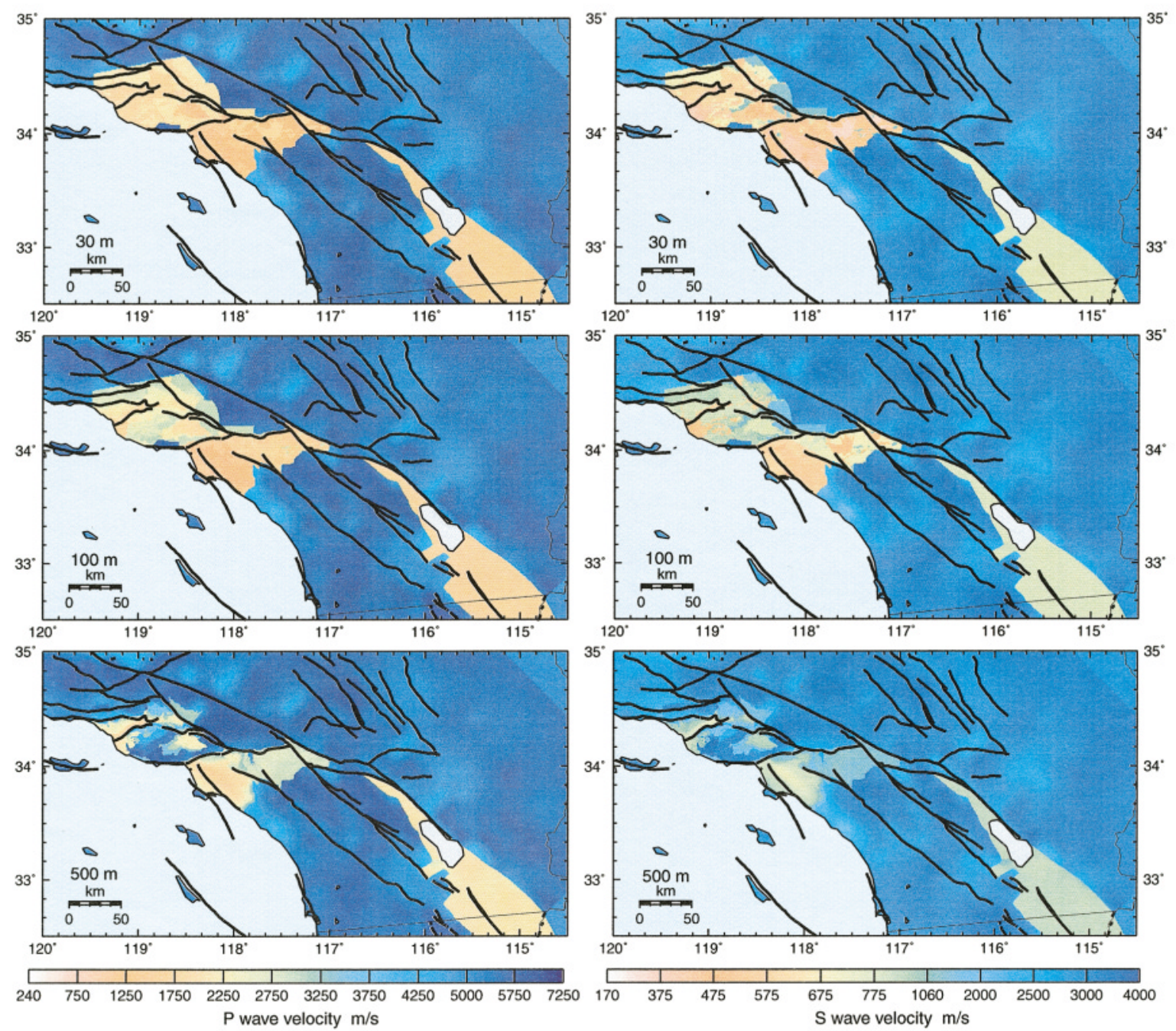

Figure 11. Depth slices though the model. Left column is $P$-wave velocity, right column is $S$-wave velocity (scales differ). The velocities are controlled by the rulebased basin models within the basins, and by tomographic results outside the basins. Depth of each slice is indicated on each panel.

20 sonic and density logs from 12 oil test wells along LARSE lines 1 and 2, Los Angeles region, California, U. S. Geol. Surv. Open-File Rept. 98-366, 53 pp.

Davis, T. L., J. S. Namson, and S. Gordon (1996). Structure and hydrocarbon exploration in the transpressive basins of southern California, in Field Conference Guide 1996, P. Abbott and J. Cooper (Editors), Pacific Section SEPM Book 80, Fullerton, California, Pacific Section AAPG GB 73, Bakersfield, California, 189-238.

Day, S. M. (1996). RMS response of a one-dimensional half-space to $\mathrm{SH}$, Bull. Seism. Soc. Am. 86, 363-370.

Department of Water Resources (1970). Meeting water demands in the Chino-Riverside area, Bulletin No. 104-3, Appendix A, The Resources Agency, Sacramento, California, 108 pp.

Dobrin, M. B. (1976). Introduction to Geophysical Prospecting, McGrawHill, New York.

Faust, L. Y. (1951). Seismic velocity as a function of depth and geologic time, Geophysics 16, 192-206.

Field, E. H. (2000). A modified ground-motion attenuation relationship for southern California that accounts for detailed site classification and a basin-depth effect, Bull. Seism. Soc. Am. 90, no. 6B, S209-S221.

Field, E. H., and the Phase III working group (2000). Accounting for site effects in probabilistic seismic hazard analyses of southern California: overview of the SCEC Phase III report, Bull. Seism. Soc. Am. 90, no. 6B, S1-S31.

Fife, D., G. Chase, R. Chapman, E. Sprotte, and D. Morton (1976). Geologic hazards in southwestern San Bernardino county, California, Calif. Div. Mines Geol. Special Report 113.

Frankel, A. (1993). Three-dimensional simulations of ground motions in the San Bernardino Valley, California, for hypothetical earthquakes on the San Andreas fault, Bull. Seism. Soc. Am. 83, 1020-1041.

Fuis, G. S., W. D. Mooney, J. H. Healey, G. A. McMechan, and W. J. Lutter (1982). Crustal structure of the Imperial Valley region, in The Imperial Valley, California, Earthquake of October 15, 1979, U.S. Geol. Surv. Profess. Paper 1254, 25-50.

Fuis, G. S., and W. M. Kohler (1984). Crustal structure and tectonism of the Imperial Valley region, California, in The Imperial Basin-Tectonics, Sedimentation and Thermal Aspects, C. A. Rigsby, (Editor), Pacific Section SEPM, Los Angeles, 1-13.

Gao, S., H. Liu, P. M. Davis, and L. Knopoff (1997). Localized amplification of seismic waves and correlation with damage due to the Northridge earthquake: evidence for focusing in Santa Monica, Bull. Seism. Soc. Am. 86, S209-S230. 

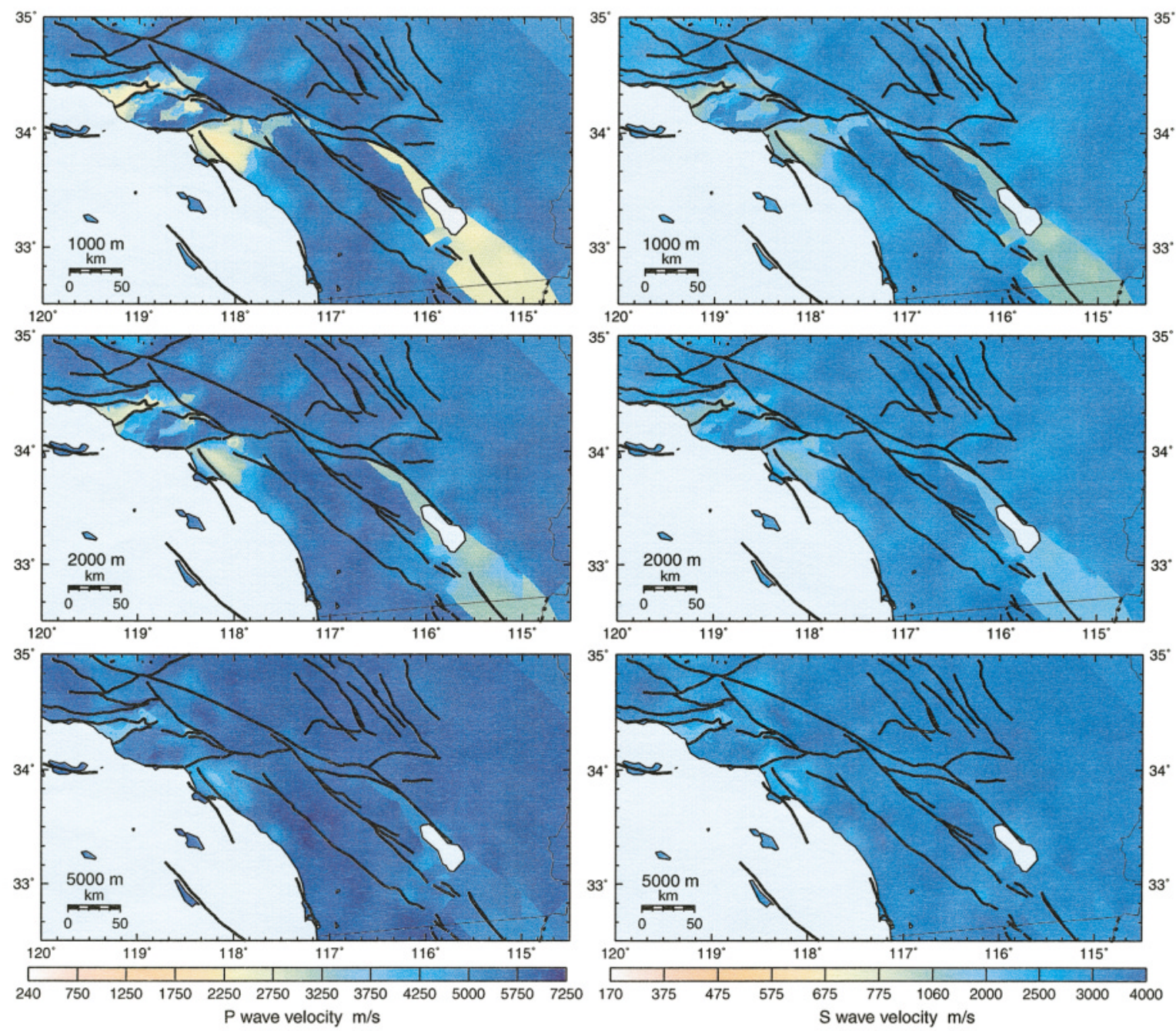

Figure 11. (Continued).

Graves, R. W. (1995). Preliminary analysis of long period basin response in the Los Angeles region from the 1994 Northridge earthquake, Geophys. Res. Lett. 22, 101-104.

Graves, R. W., D. Wald, and A. Pitarka (1999). Strong ground motion validation studies using Version 1 of the SCEC 3D seismic velocity model, poster presented at the 1999 SCEC annual meeting, Palm Springs, CA.

Hadley, D., and J. Combs (1974). Microearthquake distribution and mechanisms of faulting in the Fontana-San Bernardino area of southern California, Bull. Seism. Soc. Am. 64, 1477-1499.

Hadley, D., and H. Kanamori (1977). Seismic structure of the Transverse Ranges, California, Geol. Soc. Am. Bull. 88, 1469-1478.

Hauksson, E. (2000). Crustal structure and seismicity distribution adjacent to the Pacific and North America plate boundary in southern California, J. Geophys. Res. 105, 13,875-13,904.

Huftile, G., and R. Yeats (1995). Convergence rates across a displacement transfer zone in the western Transverse Ranges, Ventura basin, California, J. Geophys. Res. 100, 2043-2067.

Huftile, G., and R. Yeats (1996). Deformation rates across the Placerita (Northridge $\mathrm{Mw}=6.7$ aftershock zone) and Hopper Canyon segments of the western Transverse Ranges deformation belt, Bull. Seism. Soc. Am. 86, S3-S18.

Jennings, C. W. (1962). Geologic map of California Long Beach Sheet, Calif. Div. Mines Geol., Sacramento, California, Scale 1:250,000.

Jennings, C. W., and R. G. Strand (1969). Geologic map of California Los Angeles Sheet, Calif. Div. Mines Geol., Sacramento, California, Scale 1:250,000.

Lee, Y., and J. G. Anderson (2000). Potential for improving ground-motion relations in southern California by incorporating various site parameters, Bull. Seism. Soc. Am. 90, no. 6B, S170-S186.

Liu, P., and R. Archuleta (1999). Source parameter inversion using 3D Green's functions: Application to the 1994 Northridge, California, earthquake, EOS Trans. AGU. 80, p. F709.

Ludwig, W. J., J. E. Nafe, and C. L. Drake (1970). Seismic refraction, in The Sea, A. E. Maxwell, (Editor) Vol. 4, Wiley-Interscience, New York, 53-84.

Magistrale, H. (1999). Seismotectonics and crustal velocities in the Imperial Valley, California, EOS Trans. AGU. 80, F715.

Magistrale, H., H. Kanamori, and C. Jones (1992). Forward and inverse three-dimensional P-wave velocity models of the southern California crust, J. Geophys. Res. 97, 14,115-14,136.

Magistrale, H., K. McLaughlin, and S. Day (1996). A geology based 3-D velocity model of the Los Angeles basin sediments, Bull. Seism. Soc. Am. 86, 1161-1166.

Magistrale, H., R. Graves, and R. Clayton (1998). A standard three-dimensional seismic velocity model for southern California: Version 1,EOS Trans. AGU 79, F605. 
Martin, G. (1994). Proceedings of the NCEER/SEAOC/BSSC Workshop on site response during earthquakes and seismic code provisions November 18-20, University of Southern California Los Angeles.

McCulloh, T. H. (1960). Gravity variations and the geology of the Los Angeles basin of California, U.S. Geol. Surv. Profess. Paper 400-B, 320-325.

Mooney, W. D., and G. A. McMechan (1982). Synthetic seismogram modeling for the laterally varying structure in the Imperial Valley, in The Imperial Valley, California, Earthquake of October 15, 1979, U.S. Geol. Surv. Profess. Paper 1254, 101-108.

Nafe, J. E., and C. L. Drake (1960). Physical properties of marine sediments, in The Sea, M. N. Hill, (Editor) Vol. 3. Interscience, New York, 794-815.

Namson, J., and T. Davis (1992). Late Cenozoic thrust ramps of southern California, Final Report to the Southern California Earthquake Center for 1991 Contract, Davis \& Namson Consulting Geologists, Valencia, California.

Olsen, K. B. (2000). Site amplification in the Los Angeles basin from threedimensional modeling of ground motion, Bull. Seism. Soc. Am. 90, no. 6B, S77-S94.

Olsen, K. B., R. J. Archuleta, and J. R. Matarese (1996). Three-dimensional simulation of a magnitude 7.75 earthquake on the San Andreas fault, Science 270, 1628-1632.

Parsons, T., and J. McCarthy (1996). Crustal and upper mantle velocity structure of the Salton trough, southeast California, Tectonics 15, 456-471.

Rogers, T. H. (1965). Geologic map of California Santa Ana Sheet, Calif. Div. Mines Geol., Sacramento, California, Scale 1:250,000.

Rogers, T. H. (1967). Geologic map of California San Bernardino Sheet, Calif. Div. Mines Geol., Sacramento, California, Scale 1:250,000.

Roy, M., and R. Clayton (1999). Crust and mantle structure beneath the Los Angeles basin and vicinity: constraints from gravity and seismic velocities, EOS Trans. AGU 80, F251.

Silva, W., S. Li, R. Darragh, and N. Gregor (1999). Surface geology based strong motion amplification factors for the San Francisco Bay and Los Angeles areas, P.G. \& E. PEER Task 5.B Final Report, Pacific Engineering and Analysis, El Cerrito, California, 109 pp.

Steidl, J. (2000). Site response in southern California for probabilistic seismic hazard analysis, Bull. Seism. Soc. Am. 90, no. 6B, S149-S169.

Tsutsumi, H., and R. Yeats (1999). Geologic setting of the 1971 San Fernando and 1994 Northridge earthquakes in the San Fernando Valley, California, J. Geophys. Res. (submitted).
Yeats, R., G. Huftile, and F. Grigsby (1988). Oak Ridge fault, Ventura fold belt, and the Sisar decollement, Ventura basin, California, Geology 16, 1112-1116.

Yeats, R., G. Huftile, and L. Stitt (1994). Late Cenozoic tectonics of the east Ventura basin, Transverse Ranges, California, AAPG Bull. 78, 1040-1074.

Yerkes, R. F., T. H. McCulloh, J. E. Schoellhamer, and J. G. Vedder (1965). Geology of the Los Angeles basin, California: an introduction, U.S. Geol. Surv. Profess. Paper 420-A, 1-57.

Wald, D., and R. Graves (1998). The seismic response of the Los Angeles basin, California, Bull. Seism. Soc. Am. 88, 337-356.

Wessel, P., and W. H. K. Smith (1991). Free software helps map and display data, $\operatorname{EOS~72,~445-446.~}$

Wills, C. J., M. Petersen, W. A. Bryant, M. Reichle, G. J. Saucedo, S. Tan, G. Taylor, and J. Treiman (2000). A site-conditions map for California based on geology and shear wave velocity, Bull. Seism. Soc. Am. 90, no. 6B, S187-S208.

Wright, T. L. (1991). Structural geology and tectonic evolution of the Los Angeles basin, California, AAPG Memoir 52, 35-134.

Zhou, H. (1994). Rapid three-dimensional hypocentral determination using a master station method, J. Geophys. Res. 99, 15,439-15,456.

Zhu, L., and H. Kanamori (2000). Moho depth variation in southern California from teleseismic receiver functions, J. Geophys. Res. 105, 2969-2980.

Department of Geological Sciences

San Diego State University

San Diego, CA 92182-1020

(H. M., S. D.)

Seismological Laboratory 252-21

California Institute of Technology

Pasadena, CA 91125

(R. W. C.)

URS Greiner Woodward Clyde

566 El Dorado Street

Pasadena, CA 91101

(R. G.)

Manuscript received 28 July 2000 